Revista Brasil. Bot., V.32, n.3, p.539-544, jul.-set. 2009

\title{
Reproductive biology and cytology of Hypericum brasiliense Choisy (Hypericaceae) ${ }^{1}$
}

\author{
IZABEL CRISTINA RIBEIRO DE MORAES ${ }^{2}$, CECÍLIA ALZIRA FERREIRA PINTO-MAGLIO² $^{2}$ \\ and RICARDO AUGUSTO LOMBELLO ${ }^{2,3}$
}

(received: April 17, 2008; accepted: June 18, 2009)

\begin{abstract}
Reproductive biology and cytology of Hypericum brasiliense Choisy (Hypericaceae)). This is the first study of reproductive biology and cytology carried out with Hypericum brasiliense, a species with medicinal properties and potential agronomic interest. Three populations of $H$. brasiliense collected at Southeastern Brazil were studied. The results indicate that $H$. brasiliense is preferentially allogamous, self-compatible, facultative apomitic and anemophilous. Male sterility was observed in about $50 \%$ of individuals from the three populations. Anatomical studies evidenced structural abnormalities in anthers of male sterile flowers, showing enlarged tapetal cells and thick secretion deposits on the tapetal cell surfaces that may cause nutritional deficit for pollen mother cells. In cytogenetic studies several haploid chromosome numbers were observed like $\mathrm{n}=4,8,9,11,16$ and 17, including the presence of multivalents and micronuclei in tetrads, indicating the occurrence of abnormalities in the meiotic process of $H$. brasiliense. Despite these meiotic abnormalities the pollen viability and in vitro pollen germination rate observed in fertile flowers may be considered high. The diploid chromosome number $2 \mathrm{n}=16$ was observed, and the chromosomes in metaphase were small and similar. Fluorochrome staining techniques using DAPI and $\mathrm{CMA}_{3} \mathrm{were}$ applied, with no positive bands observed.
\end{abstract}

Key words - anatomy of anthers, apomixy, irregular meiosis, male sterility

RESUMO - (Biologia da reprodução e citologia de Hypericum brasiliense Choisy (Hypericaceae)). Este é o primeiro estudo de biologia da reprodução e citologia realizado em Hypericum brasiliense, uma espécie com propriedades medicinais e de interesse agronômico. Três populações de H. brasiliense da região Sudeste do Brasil foram estudadas. Os resultados obtidos dos estudos indicam que $H$. brasiliense é uma espécie preferencialmente alógama, auto-compatível, apomítica facultativa e anemófila. Foi observada macho-esterilidade em $50 \%$ dos indivíduos estudados nas três populações. Estudos anatômicos evidenciaram anormalidades estruturais nas anteras de flores macho-estéreis, como células do tapete aumentadas, com grossas camadas de secreções depositadas em sua superfície que podem originar deficiências nutricionais para as células mães do pólen. Nos estudos citogenéticos diversos números haplóides foram observados, tais como $\mathrm{n}=4,8,9,11,16$ e 17, incluindo a presença de multivalentes e micronúcleos em tétrades, indicando a ocorrência de anormalidades no processo meiótico de $H$. brasiliense. Apesar das anormalidades meióticas a viabilidade polínica e o índice de germinação in vitro dos pólens observado para as flores férteis podem ser considerados altos. O número cromossômico diplóide registrado foi $2 \mathrm{n}=16$, com cromossomos metafásicos pequenos e similares entre si. Foram aplicadas técnicas de bandamento com fluorocromos DAPI e $\mathrm{CMA}_{3}$, sem que bandas positivas fossem observadas.

Palavras-chave - anatomia de anteras, apomixia, irregularidade meiótica, macho-esterilidade

\section{Introduction}

The genus Hypericum L., included in Hypericaceae A. Juss., contains about 460 species among trees, shrubs and herbs with an almost worldwide distribution and characterized by the presence of translucent and black glands (Robson 2006). Extracts of Hypericum species have been target of studies due to their antidepressant and antitumoral properties (Bombardelli \& Morazzoni 1995, Mendes et al. 2002).

\footnotetext{
1. Part of the Masters dissertation of the first author, Programa de Pós-graduação em Agricultura Tropical e Subtropical, Instituto Agronômico de Campinas.

2. Instituto Agronômico de Campinas, Laboratório de Citogenética, Caixa Postal 28, 13020-432 Campinas, SP, Brasil.

3. Corresponding author: ricardolombello@uol.com.br
}

Although Hypericum perforatum L. is the most studied species of the genus, some studies also included Hypericum brasiliense Choisy as a source of the same secondary metabolites and medicinal proprieties related to H. perforatum (Rocha et al. 1994, 1995, Abreu et al. 2004). To increase the knowledge of this Brazilian native species, several aspects of its biology are required to be studied, such as reproductive biology and cytology. These studies provide the basis to create and maintain germplasm banks and may indicate patterns for breeding programs.

There are studies of reproductive biology in Hypericum only for $H$. perforatum. Some researchers have related the occurrence of apomixy in $H$. perforatum, recognizing this species as a facultative apomictic one, due to the occurrence of sexual and aposporic processes 
in the same plants (Noack 1939, Matzk et al. 2001, Barcaccia et al. 2006). A study of reproduction pathways of $H$. perforatum identified 11 distinct mechanisms of seed formation and observed the occurrence of pseudogamy and apospory (Matzk et al. 2001). An analysis of 55 species of the genus Hypericum demonstrated a high plasticity of reproduction pathways (Matzk et al. 2003). Moreover, male sterility was also reported for the genus (Hoar 1931, Hoar \& Heartl 1932), probably derived of abnormalities in the meiotic division. Apomixy excludes segregation and recombination during meiosis and fertilization (Koltunow et al. 2000) what may have an important role in agricultural development.

The objective of the present study is to characterize the reproductive biology and cytology of Hypericum brasiliense.

\section{Material and methods}

Seeds were obtained from three populations collected at Camanducaia-MG, Ibitipoca-MG and Ibiúna-SP, in Southeastern Brazil. In order to confirm the diploid chromosome number, root tips were pretreated with PDB ( $p$-dichlorobenzene) in satured solution at $15^{\circ} \mathrm{C}$ for 2 hours, fixed in Carnoy's solution (ethanol 3:1 acetic acid, v/v) for 24 hours and stored at $-20^{\circ} \mathrm{C}$. For slide preparation roots tips were hydrolyzed in a solution of citrate buffer with $2 \%$ of cellulase (Sigma-Aldrich) and $20 \%$ of liquid pectinase (Sigma-Aldrich) for 70 minutes at $37{ }^{\circ} \mathrm{C}$, squashed in $45 \%$ acetic acid and stained with 4',6-diamidino-2-phenylindole (DAPI) and chromomicin $\mathrm{A}_{3}\left(\mathrm{CMA}_{3}\right)$ (Schweizer 1976). For meiotic studies buds were collected and anthers squashed with acetocarmine $1.2 \%$. Pollen viability was analyzed following Alexander (1980). In vitro pollen germination test followed Conger (1953). The floral observations were carried out from July to November of 2005 and 2006. Self-compatibility test followed Kho \& Bäer (1968) protocols. Emasculated buds conserved in $2 \%$ agar solution were pollinated with their own pollen grains and observed after 6, 12, 24 and 48 hours. Emasculated buds were pollinated with pollen obtained from other individuals and used as control. Autogamy and apomixis were investigated in the two floral types indistinctly by tests carried out in greenhouse. For the first test flower buds in pre anthesis were bagged. For the second test flower buds in pre anthesis of the two floral types were emasculated and bagged. Freely pollinated flowers were used as control. The morphology of anthers was examined in histological sections of immature and mature buds. Flower buds were fixed in Carnoy's solution, dehydrated in an alcohol series and included in historesin (Gerrits 1991). The $6 \mu \mathrm{m}$ thick sections were made in a microtome and stained with Toluidine Blue. All images were captured by an Optronics DEI-750 camera and processed in Image-Pro Plus 3.0 program.

\section{Results}

Floral biology and anther anatomy - The flowers are bisexual, aromatics with 5 yellow petals and numerous stamens (35-50), ovary superior, parietal placentation, 5 carpels with numerous ovules per carpel and 5 subcapitate stigma. We observed a floral dimorphism between individuals, one pattern showing short filaments and translucent anthers, characterizing male sterility, and the other showing yellow anthers and long filaments (figures 1,2). Each individual presented only one floral type with non observed numerical predominance of one type upon the other in the three populations. In the first floral type we found empty anthers and in the second abundant pollen production. The fruits are dehiscent capsules with 110-220 seeds. Flower anthesis begins around 5:00 AM, and these flowers remain open until around 2:00 PM when the senescence begins. Fruits became mature between 10 at 12 days later. No visitors were observed in the field.
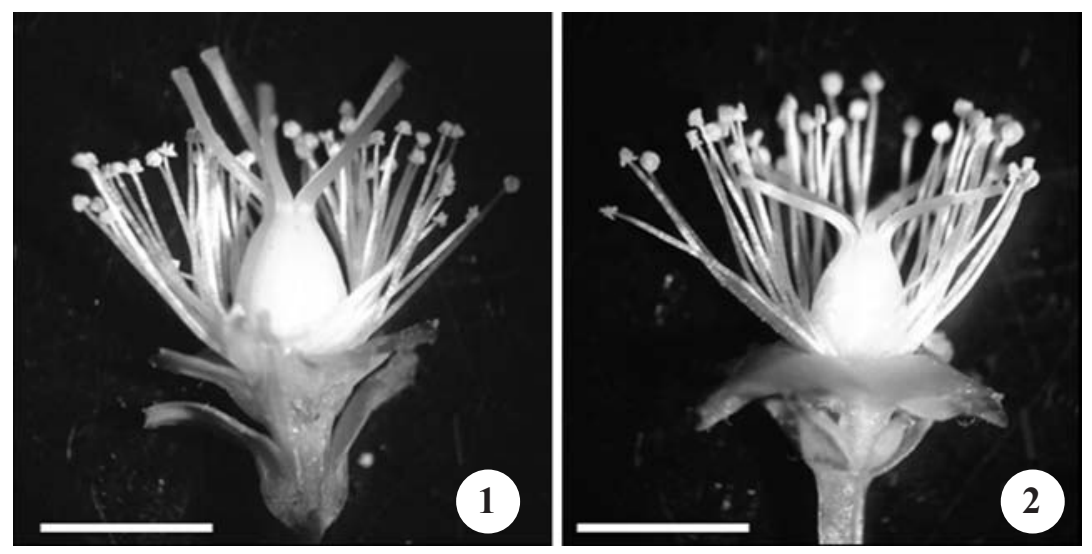

Figures 1-2. Floral dimorphism in H. brasiliense. 1. Male-sterile flower with translucent anthers and shorter stamen. 2. Fertile flower with none structural abnormality. Bar $=1 \mathrm{~mm}$. 
Abnormal anthers were also observed. Enlarged and unorganized tapetal cells and a thick deposit of sporopollenin were observed in immature anthers from sterile flowers (figure 3). Early released secretion of lipidic precursors of the pollen surface and degenerated microspores were observed in locules of sterile anthers (figure 4). Fertile flowers presented organized tapetum and viable pollen mother cells (figures 5, 6).

Cytology and reproductive biology - The diploid chromosome number observed was $2 n=16$. The most observed haploid chromosome number was $\mathrm{n}=8$, although $n=4,9,11,16$ and 17 were also registered. Normal plates of anaphase, telophase and tetrads were observed, although some abnormalities were encountered in meiotic process, such as polyvalents on metaphase I and chromosome fragments in tetrads, indicating that meiosis is irregular in this species. The DAPI/CMA staining did not show positive bands (figures 7-15).

The result for pollen viability test, which was carried out exclusively with floral buds with normal anthers, was $83.5 \%$. In vitro pollen germination test presented $43.7 \%$ of germination. Test of flower emasculation for apomixy presented $100 \%$ of fructification in male sterile plants and no fructification in fertile individuals. Selfpollination test presented $70 \%$ of fructification and free pollination tests in both floral types presented $100 \%$ of fructification.

In vitro test of pollinic tube growing in stigma showed that $H$. brasiliense is a self-compatible species.

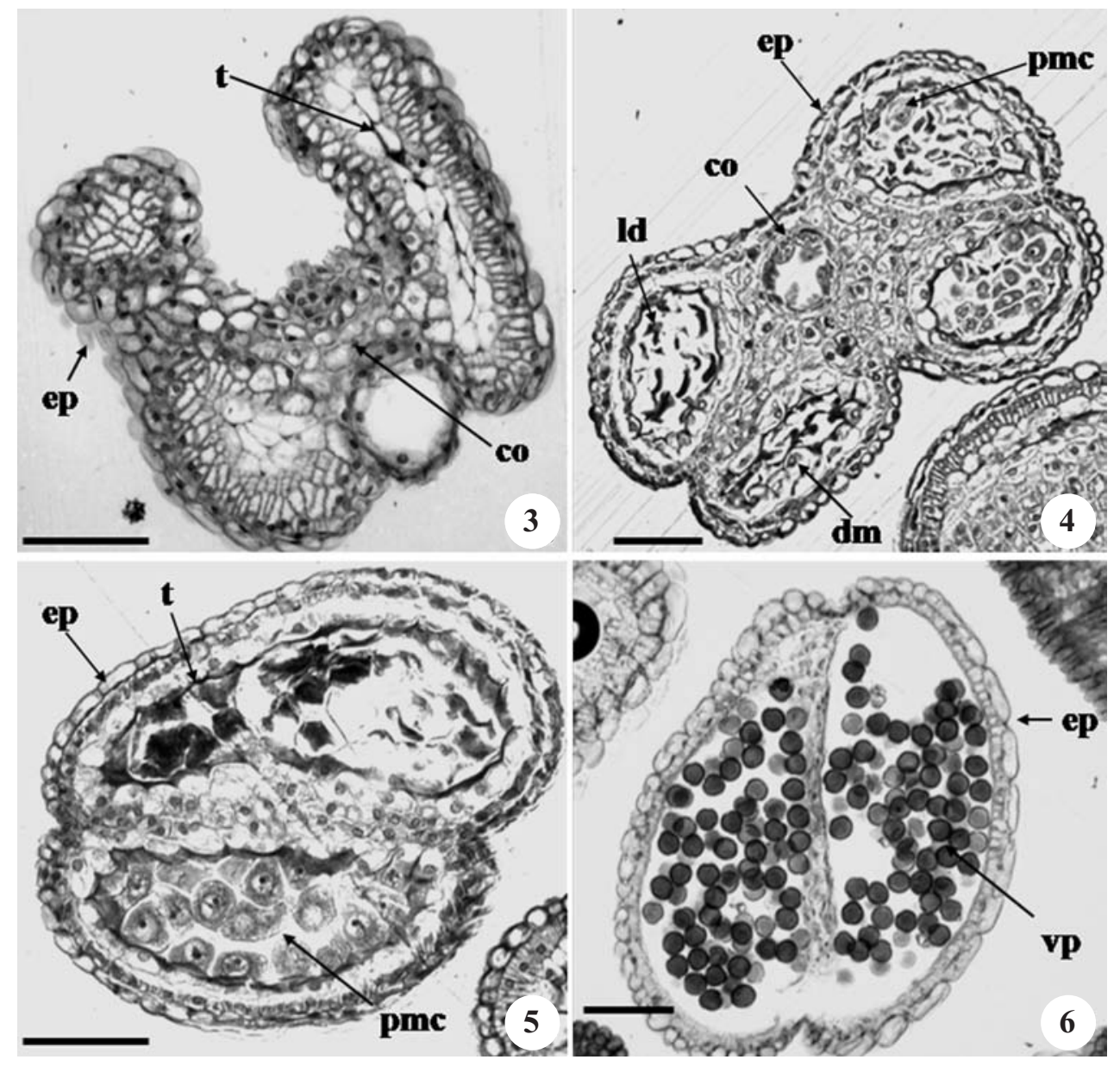

Figures 3-6. Anatomic slides of anthers of H. brasiliense stained with Toluidine Blue in different stages of development. 3. Transversal section of an immature anther from a sterile flower presenting enlarged, unorganized tapetal cells and a thick deposit of sporopollenin. 4. Locules of a sterile anther with deposits of lipidic precursors of the pollen surface on tapetal cells and some secretion released early into the locule and degenerated microspores. 5. Anther of a fertile flower in transversal section with organized tapetum and viable pollen mother cells. 6. Mature fertile anther with normal development and pollen grains apparently viable, before the dehiscence. Arrows show epidermis (ep), connective tissues (co), tapetum (t), lipidic deposit (ld), pollen mother cells $(\mathrm{pmc})$, degenerated microspore $(\mathrm{dm})$ and viable pollens $(\mathrm{vp})$. Bar $=200 \mu \mathrm{m}$. 

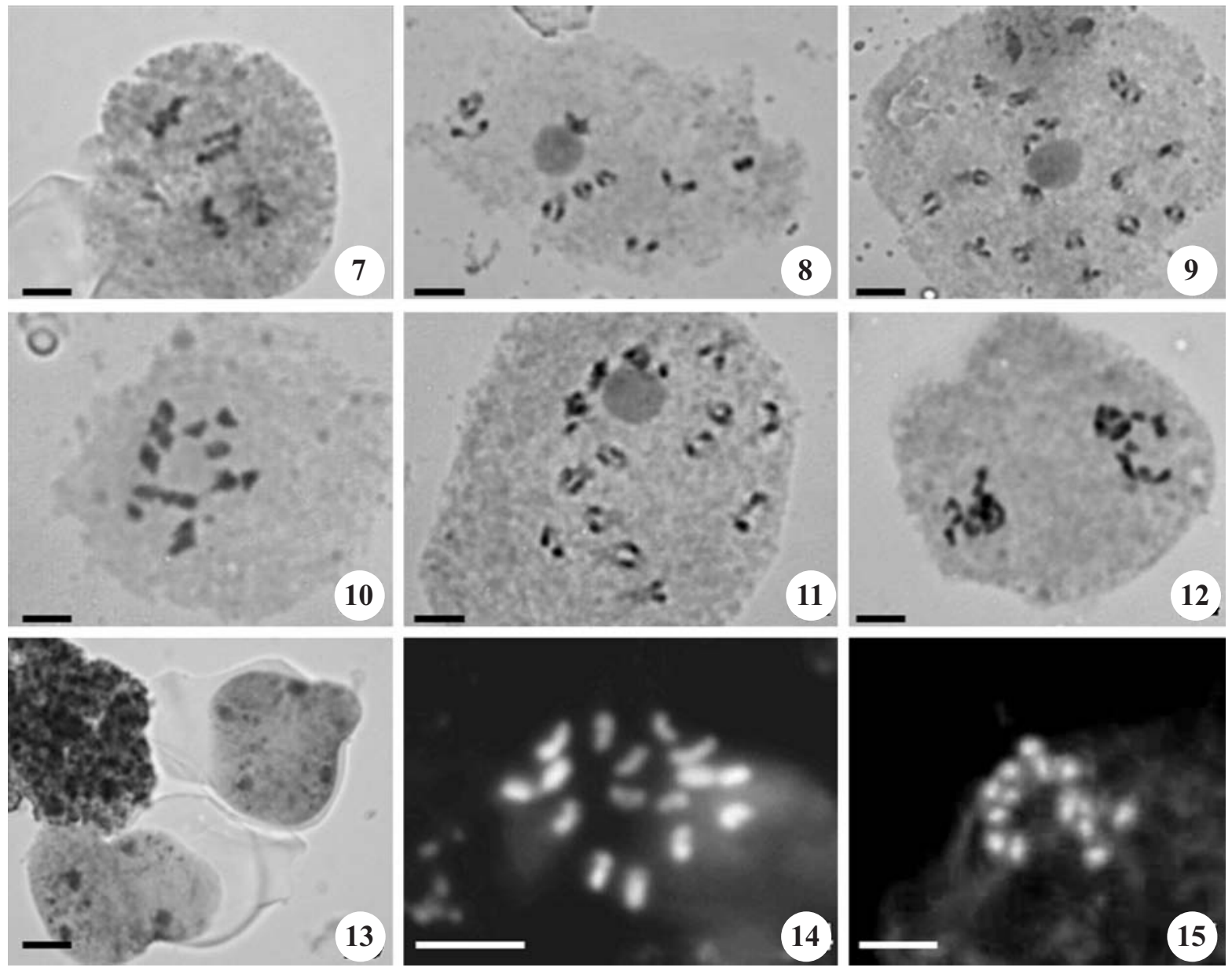

Figures 7-15. Cells of H. brasiliense in division. Figures 7 to 13 show cells in meiotic division presenting several haploid numbers. 7. Multivalents in metaphase I. 8, 9 and 11. Diakinesis with different chromosome numbers. 10. Metaphase I with $\mathrm{n}=11.12$. Telophase I apparently normal. 13 . Tetrads with micronuclei. 14. Cell in mitotic division stained with DAPI $(2 \mathrm{n}=16)$. 15. Cell in mitotic metaphase stained with $\mathrm{CMA}_{3}(2 \mathrm{n}=16)$. $\mathrm{Bar}=5 \mu \mathrm{m}$.

However the pollen tubes in cross-pollination reached the ovary in 24 hours, earlier than those of self-pollination that were observed only after 48 hours.

\section{Discussion}

The chromosome numbers registered here represented the first report for $H$. brasiliense. The diploid number $2 \mathrm{n}=16$ agrees with the basic number $\mathrm{x}=8$ related by Robson (1977) for the section Spachium, to which Hypericum belongs. There are several reports of intraspecific chromosome number variation in the genus Hypericum such as $H$. elodes with $\mathrm{n}=16$ (AlBermani et al. 1993) and $2 \mathrm{n}=20$ (Gibby 1981) and $H$. perforatum with $\mathrm{n}=16,17$, and 18 , and $2 \mathrm{n}=32$, 48 (Reynaud 1986). Hoar (1931) and Hoar \& Haertl (1932) studied meiosis in the genus Hypericum and reported the tendency of $H$. perforatum chromosomes to clump difficulting chromosome number counting. The same difficulty was found in the present chromosome study of $H$. brasiliense. We could not observe additional information about $H$. brasiliense karyology due to the reduced length of its chromosomes and the tendency to clump cited above. The absence of positive bands in the DAPI/CMA 3 staining assays may be a consequence of these features.

Despite the remarkable smell exhaled by the flowers of $H$. brasiliense, floral visitants were not observed, what suggests that these flowers are anemophilous. According to Faegri \& Pijl (1979) adaptations on floral morphology for pollen transference include adaptations also on pollen grain. For these reasons pollens of anemophilous plants tends to be smaller, dry, and are produced in higher amounts if compared to entomophilous plants pollen 
grains. These pollen features were also observed in the three populations of $H$. brasiliense studied.

The causes of the floral dimorphism here observed are probably related to cytoplasmic male sterility (CMS). Some mutations in mitochondrial genes lead to CMS, which has been described for about 150 plant species and would force out-crossing and thus contribute to genetic diversity in natural populations (Linke \& Börner 2005). Although CMS causes abortion of the male gametophyte, it does not affect female gametophytic development (Levings 1990, Chiavarino et al. 2000) as observed here for $\mathrm{H}$. brasiliense. The innermost cell layer in the locule of anther is the tapetum, which surrounds the developing pollen grains (Levings 1990) and is adjacent to the sporogenous tissue from the inside of the anther and to the middle layer from the outside of the anther (Chiavarino et al. 2000). Tapetal cells supply developing pollen by exporting nutrients and other molecules needed for pollen formation (Levings 1990). The anatomical analysis of $H$. brasiliense anthers presented abnormal deposits of secreted lipids like sporopollenin in the tapetal cells surface and early disorganization in tapetum layer. As pointed out by Shivanna \& Johri (1985) the tapetum does not seem to play any direct role in microsporogenesis until the completion of meiosis. This early degradation of the tapetal cells here observed would lead to failure to nourish developing pollen grains and their consequent abortions, as observed by Levings (1990) in a CMS line of Zea mays L. and by Fei \& Sawhney (2001) in Arabidopsis thaliana (L.) Heynh. The mutations that lead to CMS lines are involved with several features observed in male sterile species. Besides the tapetum abnormalities, we also observed short stamen and non-dehiscent anthers in $H$. brasiliense, which occurred simultaneously. These events added to some abnormalities in meiotic process such as chromosome mispairing with formation of multivalents and irregular disjunctions with micronuclei formation which were the sources of male sterility found in $H$. brasiliense. The presence of all these events in one species seems to be frequent. Sanders et al. (1999) presented a rich collection of male sterile mutants in Arabidopsis thaliana recognizing nine general classes of problems. These problems usually occur simultaneously due to the fact that they probably have the same origin, which is a mutation in one or a group of mitochondrial genes involved with CMS determination (Chase 2006).

The biology of reproduction assays indicate that $H$. brasiliense is auto-compatible and there are no barriers to self-pollination in this species, but presents preferentially cross-pollination. Although some individuals presented vestigial anthers, the tests carried out in flowers with normal anthers revealed high index of pollen viability. Variation between viable pollen index and pollen germination rate presented here is probably due to some inefficiency of in vitro germination technique. The auto-compatibility assay showed that induced selfpollination was well succeeded and the pollen tubes found no resistance to grow. However, the development of pollen tubes in cross-pollination control test was faster than that observed in self-pollination tests. The more rapid development of pollen tubes in cross-pollination results in an earlier ovule fecundation and allows to infer that $H$. brasiliense is preferentially alogamous.

The floral dimorphism observed is probably related with the reproduction pathway found in each type. Apomixis is probably the preferential mode of reproduction in populations with predominant sterile males with vestigial anthers, like that from Ibitipoca, MG. The fact that apomixis was observed only in male sterile plants characterizes $H$. brasiliense as a facultative apomitic species.

Several causes can lead to male sterility such as abortion, abnormalities in meiotic division and tetrad separation, and tapetum cells changes. Problems in exine are the mostly related responsible for male sterility in some species (Bhandari 1984). Male sterility may be associated with pseudogamy, a type of apomixis in which pollen grain is necessary only in the initial stage as a stimulus for seed formation. Possibly the apomict individuals have the male sterile pattern of anther.

The results obtained in the present study indicate high complexity and diversity of reproductive biology in H. brasiliense. Phenomena like these are possibly associated with apomixis. For better understanding the male sterility of $H$. brasiliense, ontogenic studies of anther are still necessary in order to explain the various events that lead to this condition.

Acknowledgments - The authors are grateful to Dr. Ilio Montanari of CPQBA-Unicamp for donation of $H$. brasiliense seeds, to Dra. Sandra Carmelo-Guerreiro of University of Campinas (Unicamp) for her help in anatomic studies and to Fundação de Amparo à Pesquisa do Estado de São Paulo (Fapesp) for financial support.

\section{References}

ABREU, I.N., PORTO, A.L.M., MARSAIOLI, A.J. \& MAZZAFERA, P. 2004. Distribution of bioactive substances in Hypericum brasiliense during plant growth. Plant Science 167:949-954. 
AL-BERMANI, A-K.K.A., AL-SHAMMARY, K.I.A., GORNALL, R.J. \& BAILEY, J.P. 1993. Contribution to a cytological catalogue of the British and Irish flora, 3. Watsonia 19:169-171.

ALEXANDER, M.P. 1980. A versatile stain for pollen, fungi, yeast and bacteria. Stain Technology 55:13-18.

BARCACCIA, G., ARZENTON, F., SHARBEL, T.F., VAROTTO, S., PARRINI, P. \& LUCCHIN, M. 2006. Genetic diversity and reproductive biology in ecotypes of the facultative apomict Hypericum perforatum L. Heredity 96:322-334.

BHANDARI, N.N. 1984. The microsporangium. In Embryology of Angiosperms (B.M. Johri, ed.). Springer Verlag, Berlin, p.53-121.

BOMBARDELLI, E. \& MORAZZONI, P. 1995. Hypericum perforatum. Fitoterapia 66:43-68.

CHASE, C.D. 2006. Cytoplasmic male sterility: a window to the world of plant mitochondrial-nuclear interaction. Trends in Genetics 23:81-90.

CHIAVARINO, A.M., ROSATO, M., MANZANERO, S., JIMÉNEZ, G., GONZÁLES-SÁNCHES, M. \& PUERTAS, M.J. 2000. Chromosome nondisjunction and instabilities in tapetal cells are affected by B chromosomes in maize. Genetics 155:889-897.

CONGER, A. 1953. Culture of pollen tubes for chromosomal analysis at the pollen tube division. Stain Technology 28:289-293.

FAEGRI, K. \& PIJL, L.V.D. 1979. The principles of pollination ecology. $3^{\text {ed }}$. Pergamon Press, Oxford.

FEI, H. \& SAWHNEY, V.K. 2001. Ultrastructural characterization of male sterile 33 (ms33) mutant in Arabidopsis affected in pollen desiccation and maturation. Canadian Journal of Botany 79:118-129.

GIBBY, M. 1981. Characters of the genus. In Studies in the genus Hypericum L. (Guttiferae). (N.K.B. Robson, ed.). Bulletin of the British Museum (Natural History), Botany 8:55-226.

GUERRITS, P.O. 1991. The application of glycol methacrylate in histotechnology: some fundamental principles. Rijskuniversiteit, Gröningen.

HOAR, C.S. 1931. Meiosis in Hypericum punctatum. Botanical Gazette 92:396-406.

HOAR, C.S. \& HAERTL, E.J. 1932. Meiosis in the genus Hypericum. Botanical Gazette 93:197-204.

KHO, Y.O. \& BÄER, J. 1968. Observing pollen tubes by means of fluorescence. Euphytica 17:298-302.

KOLTUNOW, A.M., JOHNSON, S.D. \& BICKNELL, R.A. 2000. Apomixis is not developmentally conserved in related, genetically characterized Hieracium plants of varying ploidy. Sexual Plant Reproduction 12:253-266.

LEVINGS, C.H. 1990. The Texas cytoplasm of maize: cytoplasmic male sterility and disease susceptibility. Science 250:943-947.
LINKE, B. \& BÖRNER, T. 2005. Mitochondrial effects on flower and pollen development. Mitochondrion 5:389402.

MATZK, F., MEISTER,A., BRUTOVSKA, R. \& SCHUBERT, I. 2001. Reconstruction of reproductive diversity in Hypericum perforatum L. open novels strategies to manage apomixis. The Plant Journal 26:275-282.

MATZK, F., HAMMER, K. \& SCHUBERT, I. 2003. Coevolution of apomixes and genome size within the genus Hypericum. Sexual Plant Reproduction 16:5158.

MENDES, F.R., MATTEI, R. \& CARLINI, E.L.A. 2002. Activity of Hypericum brasiliense and Hypericum cordatum on the central nervous system in rodents. Fitoterapia 73:462-471.

NOACK, K.L. 1939. Uber Hypericum-Kreuzungen VI. Fortpflanzungsver-haltnisse und Bastarde von Hypericum perforatum L. Zeitschrift Induktive Abstammungsund Vererbungslehre 76:569-601.

REYNAUD, C. 1986. Étude cytotaxonomique des Millepertuis du bassin Méditerranéen et des Iles Canaries. Bulletin de la Societe Botanique de France, Lettres Botanique 133:167-177.

ROBSON, N.K.B. 1977. Studies in the genus Hypericum L. (Guttiferae): 1. Infrageneric classification. Bulletin of the Natural History Museum 5:291-355.

ROBSON, N.K.B. 2006. Studies in the genus Hypericum L. (Clusiaceae). Section 9. Hypericum sensu lato (part 3): subsection 1. Hypericum series 2. Senanensia, subsection 2. Erecta and section 9b. Graveolentia. Systematics and Biodiversity 4:19-98.

ROCHA, L., MARSTON, A., KAPLAN, M., STOECKLIEVANS, H., THULL, U., TESTA, B. \& HOSTETTMANN, K. 1994. An antifungal y-pyrone and xanthones with monoamine oxidase inhibitory activity from Hypericum brasiliense. Phytochemistry 36:1381-1385.

ROCHA, L., MARSTON, A., POTTERAT, O., KAPLAN, M., EVANS, H. \& HOSTETTMANN, K. 1995. Antibacterial phloroglucinols and flavonoid from Hypericum brasiliense. Phytochemistry 40:14471452.

SANDERS, P.M., BUI, A.Q., WETERINGS, K., MCINTIRE, K., HSU, Y.-C., LEE, P.Y., TRUONG, M.T., BEALS, T.P. \& GOLDBERG, R.B. 1999. Anther developmental defects in Arabidopsis thaliana male-sterile mutants. Sexual Plant Reproduction 11:297-322.

SCHWEIZER, D. 1976. Reverse fluorescent chromosome banding with Cromomicin and DAPI. Chromosoma 58:307-354.

SHIVANNA, K.R. \& JOHRI, B.M. 1985. The angiosperm pollen: structure and function. John Wiley \& Sons, New York. 